\title{
Stepping Up the Dwindling Education Sector: An Essential Step towards A Better Nigeria
}

\author{
*Peter Okey Ejikeme [Ph. D] \\ Department of Philosophy and Religious Studies Tansian University Umunya Anambra State - Nigeria
}

\begin{abstract}
In any society, education is the means, by which citizens are equipped with the necessary attitudes, knowledge and skill that will enable them, contribute meaningfully to national and human development. The reason for this assertion is not far-fetched. This is because development in the socio-economic, technological and cultural advancement of any nation depends on the level of education of its citizens. In addition productivity improvement is a function of the quality of education provided for the citizenry. However the Nigerian education system within the last decade seemed to have been infected with the malaise (problems) of movement without motion, growth without development and quantity without quality. Hence the consistent declining forms of the Nigerian Educational System. President Goodluck Jonathan's proposed N426.53 billion for the Education sector in the 2013 budget has been greeted with commendations from stakeholders in the sector, who described it as a step in the right direction towards meeting the 26 per cent UNESCO minimum recommendation for education in every country's budget. It implies that in 2013, education will gulp 8.7 per cent of the national budget. This is the first time since independence that the Education sector will top the national budget. There is therefore the need for stepping up the dwindling nation's education sector to engender greater productivity and meaningful development of both the individual and the Nigerian nation.
\end{abstract}

\section{Introduction}

On assumption of office on May 29, 2007, President Umaru Musa Ya'radua of Nigeria outlined his development blueprint to Nigerians in what he described as seven-point agenda, geared towards vision 2020.The aim of the vision 2020 is to make Nigeria one of the twenty top/target developed economies in the world by the year 2020. Nigeria's population is predominantly youth, with young people under 35 years accounting for about 50 percent of the country's over one hundred and forty (140) million people (Federal Ministry of Youth Development, 2008). This means that in the year 2020 these young people will be the key drivers of the economy and will be the leaders in business and public services. Education was among the top in the sevenpoint agenda of President Musa Ya'radua's administration. There is no doubt that the level of development in a country is directly proportional to her system of education. In fact a high rate of development is a product of a well-organized, managed and supervised educational system. Education is the bedrock of any meaningful development. It is a means by which citizens are equipped with the necessary attitudes, knowledge and skills that will enable them contribute meaningfully to national as well as human development. Thus every nation of the world has recognized and accepted education as the springboard of societal development. For developing nations in particular, education remains a potent factor for eradicating poverty and changing the misfortune of under development. Ukeje in Ejikeme (2012) summed it up when he opined that Education is power, it is a process of acquiring knowledge and ideas that shape and condition human attitude, actions and achievements; it is a process of developing the child's moral, physical, emotional and intellectual power for his contribution in social reform; it is the process of mastering the laws of nature and utilizing them effectively for the welfare of the individual and for social reconstruction; it is the art of the utilization of knowledge for complete living.

However, Ejikeme (2011) noted that a diligent and faithful appraisal of the Nigerian educational system would reveal that we have a tragedy in our hands. The standard of the nation's education is undergoing a free fall. There is a reversal of Darwinian evolutionary theory in Nigerian education system. Instead of each successive generation of poor products to improve adaptively over preceding generations, what we have in Nigerian educational system is a progressive regression. The sound system bequeathed to us at independent by the British has been deprived of its soul through bad leadership, corruption, frequent change of policy and poor planning. More worrisome is that the progress made in various areas of the education sector within the five decades of independence was not consolidated, resulting into the undermining of the investments made in various aspects of the education sector. Nevertheless, Nigeria's philosophy of education as aptly enunciated in the National Policy on Education (2004) was based on:

a. The development of the individual into a sound and effective citizen.

b. The full integration of the individual into the community, and 
c. The provision of equal access to educational opportunities for all citizens of the country at the primary, secondary and tertiary levels both inside and outside the formal school system.

Attainment of the above stated philosophy of education presupposes the provision of quality education at all levels to the citizenry. The question however remains: have the successive governments in Nigeria been able to create the enabling environment that could lead to the achievement of the goals set out in the national policy on education through proper funding of education? It is on this premise that President Goodluck Jonathan's proposed N426.53 billion for the Education sector in the 2013 budget has been greeted with commendations from stakeholders in the sector. It implies that in this 2013, education will gulp 8.7 per cent of the national budget, though it is still below the UNESCO $26 \%$ recommendation. This is the first time since independence that the Education sector will top the national budget. This paper focuses on the various challenges facing the Nigerian education sector and calls on the stakeholders in this sector to step up action as government has made a positive move towards bettering the age long woes of this sector.

\section{MAJOR CHALLENGES IN NIGERIAN EDUCATION SYSTEM}

When the nation's education system is referred to as dwindling, it is not just saying for the fun of it. Actually there are some indices that suggest that the system is collapsing or is nearing collapse. These challenges have resulted in steep declines in educational performance, growing illiteracy levels and reduction in productivity performance. Some of the major challenges of the nation's education system are:

\section{The Quality of Teachers and Motivation}

The place of teachers in the development equation of any nation is very sacrosanct because they constitute an indispensable human resource and the single most important element in the school system. The teacher has become the pivot on which any educational development hinges. The teachers are the ones, who interpret the aims, goals and plans of education and ensure that the children are educated in the direction of those aims and goals of the society (Taiwo 1983). The teacher as a facilitator of learning has a lot of impact on the child and the society as a whole. According to Ejikeme (2001):

... teachers are the main determinants of quality in any educational system. In fact, if the learner is the centre of the educational system, the teacher is the centre of the educational quality. It is the teacher who holds the key to unlock the door of modernization. It is the teacher who determines what actually happens in the classroom. It is he who translates policies into action and theories into practice.

Recognizing the vital role of teachers in the development of education, the Nigerian National Policy on Education (2004) stated that the goals of teacher education shall be to:

a. produce highly motivated, conscientious and efficient classroom teachers for all levels of our educational system

b. Encourage further the spirit of enquiry and creativity in teachers.

c. Help teachers to fit into social life of the community and the society at large and enhance their commitment to national goals.

d. Provide teachers with the intellectual and professional background adequate for their assignment and make them adaptable to changing situations.

e. Enhance teachers' commitment to the teaching profession.

In furtherance of the above stated goals, all teachers in educational institutions are expected to be professionally trained. The teachers who shoulder the responsibility of training the young ones need to be developed to be able to perform their role, up-grade and up-date their competency within the school system. There is need for serious reforms in teacher education in order to boost the quality of products at basic, secondary and tertiary education levels. Nigeria and indeed Nigerians cannot hope for a top quality education system if the schools are staffed with second-rate teachers. The nation needs a profession that is full of inspiring, innovative, creative and knowledgeable teachers. More over, the quality of teachers in any society is largely dependent on the quality of training (pre-service and in service) received. Teachers need to up-date their knowledge and skills on a regular basis.

In addition, they need to be well motivated. What is the state of teacher preparation, education and motivation in Nigeria today? The current reality today in Nigeria in terms of teacher preparation and education is absurd. The situation portends danger for the education system. It is a situation where poor students (academically below average) from secondary schools are encouraged to apply to Colleges of Education because of the low entry 
requirements. This certainly does not augur well for the overall quality of outputs from educational institutions. The sorry state of the teaching profession was aptly captured by Okebukola (2010), when he declared thus:

"What I find pathetic is that the dregs of the class, those who are among the bottom 10 -are the ones who apply to Colleges of Education. They may have three credits, get in through pre-NCE, and after a lot of patch-patch, bribing and cheating, manage to make up to two merits with which they can combine with their ' $O$ ' level to apply for a B.Ed in the university. At the university, they are loaded with education courses and graduate with a 2.1 without any knowledge really."

Likewise, the university admission policy in Nigeria does not even help in injecting the best brains into the teaching profession. Most of the candidates admitted to read education courses are mainly those who could not reach the cut-off point in the courses of their first or second choice. Therefore the various faculties of education are populated with disgruntled and frustrated students who have no interest, motivation and commitment to the profession. Also, most of the graduate teachers in the various primary and secondary schools are there not because they are interested in the profession but because they lack alternative. How then do you make quality teachers out of these? For somebody to record high performance, there must be interest, passion, motivation and commitment.

The teaching profession has become an endangered profession in Nigeria. Everybody admits its importance yet it is treated with disdain. In the past, prospective teacher trainees were adequately catered for. They were given scholarship including free tuition, free books and free accommodation. They were assured of employment at the end of their training. All these were meant to encourage and motivate the prospective teacher trainees to enter into the enviable profession. The reverse seems to be the case nowadays. The teacher in the classroom does not even fare better. His status has waned seriously. He is no more revered, adored, respected or even recognized. He remains the least paid worker. This partly explains the surging wave of brain drain within the academia.

In Nigeria, teachers have been grossly neglected with dire effect on teachers' morale and its consequence - low quality education. The government, at all levels, has not demonstrated enough commitment to invest in teacher's welfare, maintenance and recognition. Teachers are not provided with an enabling environment to do their work efficiently and effectively. Even in the universities most departments are under-staffed and the teacher-student ratio is on the high side. The workload is too much on the teachers. A cursory observation of lecturers' activities reveals quite a lot of tasks which include but not limited to:

a. Consulting libraries, internet to have up to date information on the particular teaching subject.

b. Conducting research to improve practice

c. Writing journal articles and books for publication so as to gain promotion

d. Teaching the courses allotted

e. Conducting continuous assessment, marking and recording

f. Setting examinations for those courses

g. Loading the scores into the university's central examination data board.

h. Attending seminars, conferences and workshops, most of the time from their personal pockets.

i. Acting as cohort advisers and parents, and supervising students' projects and theses.

The list of their tasks seems endless. How do you expect somebody who is overloaded to breaking point to perform at optimal level? Nigerian teachers are really stress-ridden and are not adequately motivated.

\section{Poor Funding}

Adequate financing is essential to the success of any educational programme. Finance is the bedrock for qualitative education. According to Ejikeme (2012) no qualitative education is free, for somebody has to pay for it. Therefore, adequate resource allocation to the education sector is a necessary condition for sustainable development of the nation. With adequate funding, government at all levels would be able to plan and execute worthwhile educational projects, provide facilities for teaching and learning, expand existing facilities and infrastructure, and provide enhanced conditions of service for both the teaching and non-teaching staff (Famade, 2002). Over the years, government resource allocation to education has been on the increase. This could be attributed to the fact that education is regarded as an investment yielding dividends by way of manpower supply (Longe, 1985). However, education financing in Nigeria today is not only haphazard, but highly inadequate. No thanks to the economic depression of the 1980s that have a most devastating effect on developing countries, Nigeria inclusive. 
There is increasing evidence of financial constraints, thus the proportion of the government budget and Gross National Product (GNP) devoted to education has been on steady decline. Though at the various levels of government - local, state and federal, there seems to be high budgetary provisions for education, the fact remains that the substantial part of the impressive rise in educational expenditure is not real but rather a reflection of the level of inflation in the economy (Famade, 1999). The truth of the matter is that the level of financial availability calculated as the percentage of public expenditure allocated to education in relation to total budget has always been declining over the years. The lack of sufficient funds and the escalating cost of financing the education system have placed the government in a sort of dilemma.

\section{Decaying Infrastructure}

Infrastructural facilities are the physical and special provisions made to enhance teaching and learning in schools. The importance, need and relevance of physical resources towards the success of every educational programme have always been emphasized. The availability of adequate school buildings, classrooms, chairs, desk and other facilities are necessary for the attainment of educational objectives. Hallak (1990) identified educational facilities as the major factor contributing to academic achievement in the school system. These include the school buildings, classrooms, furniture, libraries, laboratories, recreational equipment, apparatus and other instructional materials. While the availability, relevance and adequacy of these resource items contribute to academic achievement, the scholar acknowledged the fact that unattractive school buildings, crowded classrooms, absence of playing ground and surrounding devoid of aesthetic appearance can contribute to poor academic attainment. Olutola (1981) noted that availability of school buildings and other plant facilities are important factors contributing to good academic performance as they enhanced effective teaching and learning activity. Williams (1973) however argued that though buildings are vital input into the educational system, expensive structures may not necessarily improve academic achievement. Obemeata (1995) however held a contrary view as he stated that:

It is necessary that efforts should be made to renovate the dilapidated school buildings in the country as experience has shown that primary schools that produce the best results in the National Common entrance Examination and the secondary schools that have the best school certificate results, and whose products have been adjudged to be good, are not the ones with dilapidated buildings and overcrowded classroom, but the ones that have good and attractive buildings and have classrooms with about 40 pupils as opposed to those with between 70 and 80 pupils.

Today in Nigeria, few especially in Edo and Rivers states, of the public schools can boast of good infrastructure. Most of the public schools are full of decay infrastructure. The equipment of yesteryears are still the same equipment being used now. In some places, they are grounded and the facilities are not there any longer. Routine maintenance, according to Ogonor and Sanni (2001) is a way of ensuring that facilities and equipment are serviced regularly and that they attain their maximum life span by preventing breakdown before they occur. But in Nigeria, there seems to be no culture of facilities maintenance. Once a school building or other physical structure has been commissioned, every other thing about the structure is usually forgotten. Thus, it was not unusual to find that most schools built over several decades ago have had no renovation, even when it was obvious that such structures have dilapidated or become obsolete.

\section{Poor Student Performance at Public Examinations}

Nigeria's educational system which has been on a downward spiral quality-wise, has virtually become totally dysfunctional. Today, it has become increasingly difficult to match content with practice. There has been a gradual but steady increase in failure rates of the secondary school students in public examinations. The performance of students in public examinations, such as West African Examination Council (WAEC), National Examination Council (NECO) and Joint Admissions Matriculation Board (JAMB), in Nigeria has been consistently poor and worrisome in recent years.

In an analysis of the results of the West African Secondary School Certificate Examinations (WASSCE), the candidates who obtained credit passes in at least five subjects including English Language and Mathematics, within the period of 2005-2009 are as follows:

$\begin{array}{lc}\text { YEAR } & \text { PERCENTAGE } \\ 2005 & 27.53 \\ 2006 & 15.56 \\ 2007 & 25.54 \\ 2008 & 13.76 \\ 2009 & 25.99\end{array}$


Source: Uduh (2010)

In like manner, the performance of the candidates in the November/December, 2010 Senior Secondary Certificate Examination conducted by National Examination Council (NECO) reveals the same abysmal failure. Releasing the result, Okpala (2011) said:

"Of the 256,840 registered candidates, 256,827sat for the examination. No fewer than 51,781 of 235,933 candidates (20.16\%) passed English Language; while 87,508 of the 234,959 candidates (34.18\%) who sat for Mathematics had credit pass",

The same poor performance is witnessed in November/December 2012 NECO result. According to The Nation Newspaper of Wednesday, 20 ${ }^{\text {th }}$ March 2013:

...only 33 percent of the 83,755 candidates who sat for the English Language paper passed at the required credit level. Only 25,628 of the candidates could achieve their dream this year. While the performance in Mathematics was above 50 percent mark, it was not so in the sciences. In physics, less than one percent of 35,000 who sat for the examination passed at credit level, while in chemistry it was 35 percent.

The above distressing statistics capture the fears of parents, governments and employers of labour about the enormity of the problem at hand. Though the situation has not always been this bad, but things got progressively worse when societal values began to be eroded by crass materialism, corruption, bad leadership and abdication of responsibility by political jobbers, posing as political leaders. More worrisome is the virtual neglect of the education sector by all the stakeholders. Parents, religious and traditional institutions have abandoned their responsibilities to the students. They have left all to the schools - the teachers and school administrators, forgetting that they have limited time and powers over the students. The poor performance of the candidates in public examinations reflects the level of wastage at the senior secondary schools. A number of factors have been identified as the causative factors responsible for the poor performance in examinations. These factors according to Uduh (2011) include but not limited to:

a. Student's inadequate preparation and poor coverage of the syllabus.

b. Failure on the part of students to adhere to instructions.

c. Lack of understanding of the demands of the question which is due to poor reading culture

d. Illegible handwriting and poor spellings

e. Shortage of qualified teachers

f. Inadequate facilities

g. Lack of good school environment

h. Examination malpractices

It is instructive to note that the low quality of instruction imparted by teachers who are not too well grounded in the art and science of their profession is a major cause of concern. There is also the ever growing tribe of students whose basic worldviews have been corroded by warped social values and in an environment that is far from being conducive for learning.

Another worrisome practice in Nigeria is that too much value is placed on certificate rather than performance. This provides a fertile ground for the students to obtain certificates with every means possible - fair or foul. Hence, their engagement in examination malpractices. It is important to note that examination malpractice encompasses any fraudulent step taken towards achieving an undeserved and un-merited success at examinations. Malpractices in examinations is however not limited to students alone. Quite a number of parties, for reasons best known to them aided and abetted examination malpractices. These accomplices include:

a. School teachers who fail to attend classes regularly to prepare their students prior to examinations

b. Parents who bribe admission/examination officials to secure admission letter

c. Security officials who jettisons the security confidence reposed in them to reveal examination questions before examination date

d. Officials charged with the packaging of examination questions for designated centres but smuggles such questions out and make them available before the date of examination.

e. School proprietors who present candidates for public examinations and bribe examination officials and supervisors/invigilators to perpetuate malpractices

f. Government that provides little or no input of infrastructure and other materials and adequate funds but frowns at poor results. 
The above scenario has implication for national development. This is because no nation can develop beyond her educational content. The two major effects of examination malpractice on the nation are that:

a. It turns the graduate into mediocre, rogues and fraudsters, and

b. The certificates obtained from such fraudulent practice will be unfit for the job market as the owner will not have the intellectual/mental capacity to defend it.

\section{Conclusion And The Way Forward}

There is no denying the fact that education constitutes a vital component of the Millennium Development Goals (MDGs) which will shape the nature of social and economic progress in Nigeria for the foreseeable future. For young people, their need is education. It is important therefore to develop the young ones physically, mentally and psychologically because they are the future of this country. However, with about eighty percent failure rates there seems to be no future. Even though leadership is so important but the leaders are not concerned about the welfare of the people. Their major pre-occupation is acquisition of material wealth and keeping themselves in power at all cost. There is no serious thinking going on for the future of the country. There is a value dislocation, cultural dislocation and so much primitive capital accumulation by the leaders.

Over the years, the Nigerian university system which had hitherto enjoyed international recognition and respectability for its global competitiveness has suddenly become a shadow of itself. Nigeria's education sector, to say the least, is in a mess; having suffered from sustained neglect over the years by successive governments. The sector is beset by inadequate funding, poorly motivated and unqualified staff and decrepit infrastructure resulting in steep declines in educational performance, low productivity, growing illiteracy levels, and increased vulnerability to disease. These challenges have resulted in very unflattering estimates of the quality of life in Nigeria. This distressing scenario was vividly captured by the United Nations Development Programme in its 2011 International Human Development Indicators (HDI), as it puts life expectancy in Nigeria at 48.4 percent while eight percent of the population is undernourished. The report further revealed that Nigeria spent a meager 0.9 percent of her Gross Domestic Product (GDP) on education.

Today, as we have noted earlier, only few public schools (especially in Edo and Rivers states) can boast of good infrastructure. The quality of instruction in most public schools is well below average. Teaching is handled by teachers who seem not to be qualified and who are not knowledgeable enough. The teachers are too poorly paid and motivated that they have no option but to become emergency businessmen and women. The problem is further compounded by poor funding of education with the result that strikes by various unions in the educational sector have literally crippled the system. Worse, successive administrations have played bad politics with various policies that have not really advanced the cause of education.

Consistently, inconsistent educational policies have caused a great deal of confusion in the educational system. At some point, there was a policy on Universal Primary Education (UPE), followed by Universal Basic education (UBE). Currently, attempts are on top gear to review the policy. The problems in the education sector are not on government alone. Other stakeholders who are implementers of government policies should be alive to their responsibilities. The government and other stakeholders should give greater attention to education as a means of facilitating rapid socio-cultural and economic development of the country. The nation must start to expand its scope in education as it needs both quantity and quality teaching facilities to improve the sector. There is the need for government to invest in staff development. The nation must get back to the training and recruiting of good, committed teachers right from the primary school level. Once the foundation is right, it can readily and easily be built upon at other higher levels. The teachers need exposure. They should be sponsored abroad for short courses where they can interact with other teachers and learn how to use gadgets in teaching. More capable teachers - those who have passed the rigors and rudiments of training in the profession - should be employed to reduce teacher-student ratio and break the tasks into smaller units so that the teachers will devote more time, energy, strength and health to operate at their optimum level without hindrance.

Government must work to improve both the quality of education and expand access to it for Nigerians. To achieve this, the government at the centre must work closely with the state and local governments to enhance the uniformity of standards, the maintenance of infrastructures, and the coordination of strategies. Government should fund education more vigorously. The current human capital flight in the tertiary institutions is attributed to poor funding and lack of infrastructure. Also, the acute shortage of manpower and dearth of qualified personnel in the right mix, quantity and quality, particularly in the sciences and technology is equally attributed to lack of funds and other infrastructures needed to hire and produce the right caliber of staff in these critical fields. 
The educational institutions should pay serious attention to the key elements necessary for the award of a certificate - character and learning. Anyone found to be deficient in either or both of these parameters should be made to remedy such deficiencies before they are released to the labour market. Teachers should take their job more seriously. They should prepare their students well and make sure they cover the syllabus before examinations. Students too should familiarize themselves with the rubrics of the past questions, write legibly and pay attention to details. They should develop a positive attitude to examinations. It is sad to note that in some tertiary institutions, many students pay their lecturers to give them pass marks, while certificates are also bought. Some parents are not patient but rather look for manipulative ways of making their children pass examinations. To actually have quality education lecturers and administrators in Nigerian Universities must also upgrade their moral values and ethical standards in doing their jobs. For any hope of having quality education in Nigeria a reorientation on the value system might be necessary here.

If all the above measures are put in place, the dwindling Nigerian education system will be stepped up for enhanced productivity.

\section{References}

[1] Bello-Osagie, k \& Olugbamila, A.(2010). Education: The Journey so far.The Nation, vol. 5, No 1534,

[2] p.21 September 30.

[3] Ejikeme, P. O. (2001) Consequences of Decline in the number of Male Teachers on Human Development Among Secondary Schools in Enugu State. (M ed. Thesis, Faculty of Education, Enugu State University of Science and Technology, ESUT).

[4] Ejikeme P. O. (2011). Corruption and the collapse of Education in Nigeria. Pope John Paul II Annual Memorial Lecture series, No. 6. Pope John Paul Seminary Awka.

[5] Ejikeme, P. O. (2012) Education for Sustainable Development: A Lead Paper Presented At Agbako Youth/Students Convention 2012 Organized By Agbako Village through Education and Development Committee, $23^{\text {rd }}$ December 2012

[6] Famade, O.A. (1999). Funding education in a Depressed Economy;The Policy Options.In Fadipe, J.O

[7] \&Oluchukwu, E. E. (Eds)Educational Planning and Administration in Nigeria in the21 st century. Ondo

[8] NIEPA.

[9] Famade, O.A. (2002). Towards the successful Implementation of theUBE scheme in Nigeria: A consideration of some planning Strategies. In Ajayi, T; Fadipe, J.O.; Ojedele, P.K. \&Oluchukwu, E.E. (Eds) Planning and Administration of Universal Basic Education in Nigeria. Ondo NIEPA

[10] Federal Republic of Nigeria. (2004). National Policy on Education, 4thedition, Lagos: NERDC Press Hallak, J. (1990). Investing in the future: setting educational priorities in the developing world. Paris: UNESCO - IIEP

[11] Lassar, N.P. (1993). The teacher of the 21st century. A key note address delivered at a workshop on transition from senior secondaryschools to colleges of education, held at Hill station Hotel, Jos. 8 - 10 November

[12] Longe, R.S. (1985). Economic Accountability and Productivity measurement in secondary education. In inanga, E.J. (Ed) Managing Nigeria's Economic System: A Book of Readings. Ibadan: Heinemann Educational Books (Nig) Ltd.

[13] Obemeata, J.O. (1995). Education: An Unprofitable industry in Nigeria. Postgraduate school interdisciplinary Research Discourse. University of Ibadan.

[14] Ogonor, B.O. \&Sanni, G.A (2001).Maintenance of secondary school facilities in Midwestern Nigeria.

[15] In Nwagwu, N.A.; Ehiametalar, E.T; Ogunu, M.A, \& Nwadiani, M. (Eds) Current Issues in Educational Management in Nigeria. Benin-City. NAEAP.

[16] Okebukola, P. (2010). Whither Education in Nigeria. A lecture delivered at the launch of Alfred Debbie Opal Foundation, Lagos, 15 th July.

[17] Okpala, P. (2011), NECO records another mass failure. The Nation,vol.6, no 1715, p.4, March 31st .

[18] Olutola, A. (1981), school plant planning and maintenance. In Adesina, S (Ed) Introduction toEducation planning. Ile-Ife; University of Ife Press Ltd.

[19] Taiwo, C.O. (1983). The Nigerian education system: Aims, Plans and Implementation. In Adesina, S; Akinyemi, k \& Ajayi, K. (Eds) Nigerian Education: trends and Issues. Ile-Ife university of Ife, Press Ltd.

[20] Uduh, C. (2010). Report released at a seminar on overcoming candidates Poor performance at the west African Senior School certificate examination. 25th June.

[21] UNDP (2011).International human development indicators, 2011 UNDP.

[22] Williams, J.D. (1973). Efficiency of education.In Lowe, J; Grant \& Williams, J.D (Eds) Education and national buildings in the thirld world. Ibadan: Onibonje Press \& Book Industries (Nig) Ltd.

[23] Zuofa, (2008).Moving Bayelsa State Forward through Qualitative education: An Imperative. Niger Delta Journal of education,(1), $1-9$. 